The Research, Development and Statistics Directorate exists to improve policy making, decision taking and practice in support of the Home 0 ffice purpose and aims, to provide the public and Parliament with information necessary for informed debate and to publish information for future use.

Findings are produced by the Research, Development and Statistics Directorate. For further copies contact:

Communication Development Unit Room 275,

Home 0 ffice,

50 Q ueen A nne's $\mathrm{G}$ ate, London SW 1 H 9 AT.

Tel: $\quad 02072732084$

Fax: 02072220211

publications.rds@homeoffice.gsi.gov.uk

\title{
An evaluation of the literacy demands of general offending behaviour programmes
}

\author{
Karen Davies, J une Lewis, Janet Byatt, Emily Purvis and Brian Cole
}

Anecdotal evidence from tutors delivering accredited programmes, including general offending behaviour programmes, has suggested that offenders with literacy problems may struggle with programmes and that some demanded a high level of literacy (Hollin et al., 2002). The key findings summarised here are from a study which aimed to provide evidence about the literacy demands of three accredited general offending behaviour programmes delivered in six probation areas: Think First, Enhanced Thinking Skills and Reasoning and Rehabilitation. The skill levels required for these programmes were assessed and compared with the literacy skills of the offenders required to attend them, to determine whether any mismatch exists.

\section{Key points}

Reading and writing:

- the reading and writing demands of the programmes were high

- there was a regular and consistent demand for reading skills at Level 1 (the level expected of a competent 11-year-old and Level 2 (GCSE A*- C))

- there were fewer and lower demands for writing skills, usually at Entry 3 (the level expected of a competent 9-year-old) and Level 1

- the reading and writing levels of the offenders in this study were low - $57 \%$ had skills below Level 1.

- Speaking and listening:

- the speaking and listening demands of the programmes were very high - at Level 2, and sometimes at Level 3 or beyond. This is at or beyond the level of G CSE A*- C

- the speaking and listening levels of some offenders were low - $35 \%$ had skills which were probably below Level 1 .

- This evidence suggests that for many offenders, the literacy demands of the three programmes exceeded their literacy skills. There was also evidence that there were problems for some tutors in adjusting the delivery of the programmes to accommodate the high literacy needs of some offenders.

The premise of general offending behaviour programmes is to change offenders' attitudes and behaviour by using cognitive behavioural methods. These teach offenders how to analyse and change their thinking in order to avoid patterns of behaviour that can lead them to offend. The implementation of these programmes in the correctional services follows international evidence suggesting they can be effective in reducing reconvictions (Vennard, Sugg and Hedderman, 1997). These programmes are typically delivered in classroom type settings and require offenders, for example, to listen to tutors, read hand-outs, participate in group discussions and complete written exercises. 


\section{Definition of literacy}

For the purposes of this study the definition was: 'The ability to read, write, listen and speak in English, at a level necessary to function and progress at work and in society in general' (adapted from DfEE, 1999).

Anecdotal evidence from tutors delivering accredited programmes, including general offending behaviour programmes, has suggested that offenders with literacy problems may struggle with programmes and that some demanded a high level of literacy (Hollin et al., 2002). Table 1 shows the different levels of adult literacy. There has been some evidence that offenders have lower levels of literacy than adults in the general population. A recent survey (DfES, 2003) found that $16 \%$ of adults aged from 16 to 65 years had literacy skills at Entry 3 or below. In comparison, a DfEE study (2001) states that $50 \%$ of prisoners and those supervised in the community had poor reading skills and $81 \%$ had writing skills below Level 1 .

\begin{tabular}{|c|c|c|}
\hline $\begin{array}{l}\text { National } \\
\text { Standard }\end{array}$ & $\begin{array}{l}\text { At this level adults are } \\
\text { able, for example to }\end{array}$ & $\begin{array}{l}\text { ational } \\
\text { Curriculum level }\end{array}$ \\
\hline Entry 1 & $\begin{array}{l}\text { Read and obtain information } \\
\text { from common signs and } \\
\text { symbols }\end{array}$ & $\begin{array}{l}\text { Level } 1 \\
\text { (age 5) }\end{array}$ \\
\hline Entry 2 & $\begin{array}{l}\text { Use punctuation cor rectly, } \\
\text { including capital letters, full } \\
\text { stops and question marks }\end{array}$ & $\begin{array}{l}\text { Level } 2 \\
\text { (age } 7 \text { ) }\end{array}$ \\
\hline Entry 3 & $\begin{array}{l}\text { O rganise writing in short } \\
\text { paragraphs }\end{array}$ & $\begin{array}{l}\text { Level } 3 \\
\text { (age 9) }\end{array}$ \\
\hline Level 1 & $\begin{array}{l}\text { Identify the main points and } \\
\text { specific detail in texts }\end{array}$ & $\begin{array}{l}\text { Level } 4 \\
\text { (age 11) }\end{array}$ \\
\hline Level 2 & $\begin{array}{l}\text { Read and understand a range } \\
\text { of texts of varying complexity } \\
\text { accurately and independenty }\end{array}$ & $\begin{array}{l}\text { GCSE A*-C } \\
\text { (age 16) }\end{array}$ \\
\hline \multicolumn{3}{|c|}{$\begin{array}{l}\text { Note: Source: DfES } 2003 \text {. } \\
\text { Level } 3 \text { is not covered by National Standards but by the } \\
\text { Q ualifications and Curriculum Authority Key Skills Level } 3 \text { for } \\
\text { communication skills, which does not map directly to the } \\
\text { National Curriculum. See Qualifications and Curriculum } \\
\text { A uthority } 1999 \text { for further details. }\end{array}$} \\
\hline
\end{tabular}

\section{Methodology}

Data collected between 0 ctober 2002 and May 2003 included:

- the programmes' literacy demands, through mapping of manuals against $\mathrm{N}$ ational Standards for literacy (Table 1) where available and, where demands were above Level 2, the Key Skills Standards

- the literacy levels of offenders, using three assessment tools (see Methodological note)

- the extent to which the literacy demands of the programme materials were mediated by tutors through observation of sessions and videotapes

- the views of programme tutors and offenders through questionnaires and interviews.

Six probation areas took part in the research, with two areas running each programme - Think First, Enhanced Thinking Skills (ETS) and Reasoning and Rehabilitation
$(R \& R)$. A reas were asked to conduct literacy assessments on all offenders referred to the programmes (usually before the offenders started the programmes) during the data collection period until they had reached 100 assessments during the data collection period. O ne area joined the research project late and was therefore set a lower target. Usually offenders were assessed for reading and writing first, followed by speaking and listening assessment at a later date. This meant that slightly fewer speaking and listening assessments were conducted than the reading and writing a ssessments.

\section{Offenders' assessment results}

Data from the initial assessment test, which assesses reading and some writing skills from pre-Entry to Level 1 , were supplied for 473 offenders. 0 ffenders who achieved Level 1 on the initial assessment (203) were then tested for reading comprehension at Level 2 . Speaking and listening results were supplied for 455 offenders.

In order to determine the representativeness of the offenders in the study, data collected on age and risk of reoffending scores were compared to the age and risk or roffending scores of other groups of offenders. This suggested that there were similarities between average ages and risk scores for offenders in this study with those on general offending behaviour programmes nationally and with Think First in particular.

Initial assessment results - reading and some writing skills A high proportion $(57 \% n=270)$ of offenders had skill levels below Level 1 for reading and writing, i.e., below the level of a competent 11-year-old. W ithin this group:

- $17 \%(80)$ of offenders were at or below Entry 2, the level of a competent 7 -year-old or less in these skills

- $1.7 \%$ (8) of offenders were pre-literate, that is, not able to read a sentence.

Assessment of reading skills at Level 2

As this assessment was a new test based on the Diagnostic Assessment tools (DfES, 2003), data were analysed to consider the performance of the test. The analysis suggested that the test related well to the scores achieved on the initial assessment. Although further work is recommended on developing this test, the results were encouraging. Results of the assessments were:

- $22 \%(45)$ of the offenders who achieved Level 1 on the initial assessment achieved Level 2 in reading comprehension

- $9.7 \%$ (46) of offenders overall achieved Level 2 in reading comprehension.

Speaking and listening

Results from the speaking and listening assessment should be interpreted cautiously, due to slight variations in data from probation areas. A number of factors may have contributed to these variations - the robustness of the checklist itself, the limited training available for probation staff within the study and the lack of knowledge amongst staff of the N ational Standards for speaking and listening. These factors should be explored in further research. However, analysis of the data collected from the assessments of speaking and listening and initial assessment showed that, in general, offenders' scores were at or above the levels of their initial assessment results. 
Table 2 Reading and w riting demands of the programmes compared with offenders' skills

\begin{tabular}{|c|c|c|c|}
\hline Programme & $\begin{array}{l}\text { Proportion of sessi } \\
\text { for reading }\end{array}$ & $\begin{array}{l}\text { emands at Levels } 1+2 \\
\text { for writing }\end{array}$ & O ffenders' levels' $(n=473)$ \\
\hline $\begin{array}{l}\text { ETS } \\
20 \text { sessions }\end{array}$ & $\begin{array}{l}\text { Level 1: } 100 \% \\
\text { Level 2: } 35 \%\end{array}$ & Level 1: $65 \%$ & \multirow{3}{*}{$\begin{array}{l}57 \% \text { below Level } 1 \\
43 \% \text { at Level } 1 \text { and above } \\
10 \% \text { at Level } 2 \text { for reading comprehension }\end{array}$} \\
\hline $\begin{array}{l}\text { Think First } \\
22 \text { sessions }\end{array}$ & $\begin{array}{l}\text { Level 1: } 50 \% \\
\text { Level 2: } 68 \%\end{array}$ & $\begin{array}{l}\text { Level 1: } 36 \% \\
\text { Level 2: } 9 \%\end{array}$ & \\
\hline $\begin{array}{l}R \& R \\
38 \text { sessions }\end{array}$ & $\begin{array}{l}\text { Level } 1: 53 \% \\
\text { Level } 2: 37 \%\end{array}$ & Level 1: 11\% & \\
\hline
\end{tabular}

Further work is recommended to develop an assessment of speaking and listening skills, although this relationship between the two tests is encouraging as the initial assessment has been extensively piloted. Findings from the data showed that:

- $35 \%$ (159) of offenders were probably below Level 1 for speaking and listening

- $26 \%$ (118) of offenders probably had speaking and listening skills at Level 2 or above

- the speaking and listening skills of offenders aged 18-24 years were probably poorer than those of offenders aged 25 years and older.

Literacy demands of general offending behaviour programmes

The overall level of demands was high, although there were variations in reading and writing demands for each programme (Table 2 ). Demands for reading skills at Level 2 ranged from $35 \%$ of sessions in ETS to $68 \%$ in R\&R. $65 \%$ of ETS required writing skills at Level 1 (due to use of assignments) compared with $11 \%$ of $R \& R$.

The data indicated that all three programmes consistently demanded very high levels of speaking and listening skills, at Level 2 and Level 3. The results of this analysis are summarised in Table 3. There may also have been cumulative effects, in that offenders were faced with demands for very high skills levels at most sessions. In particular, there were high demands in the first three sessions of each programme in reading, speaking and listening.

\begin{tabular}{|c|c|c|}
\hline Programme & $\begin{array}{l}\text { Sessions with speaking } \\
\text { and listening demands } \\
\text { at Levels } 2+3\end{array}$ & $\begin{array}{l}\text { O ffenders' levels } \\
(n=455)\end{array}$ \\
\hline $\begin{array}{l}\text { ETS } \\
20 \text { sessions }\end{array}$ & $\begin{array}{l}\text { Level 2: } 100 \% \\
\text { Level 3: } 60 \%\end{array}$ & \multirow{3}{*}{$\begin{array}{l}35 \% \text { probably } \\
\text { below level } \\
26 \% \text { probably at } \\
\text { Level } 2 \text { or above }\end{array}$} \\
\hline $\begin{array}{l}\text { Think First } \\
22 \text { sessions }\end{array}$ & $\begin{array}{l}\text { Level 2: } 95 \% \\
\text { Level 3: } 45 \%\end{array}$ & \\
\hline $\begin{array}{l}R \& R \\
38 \text { sessions }\end{array}$ & $\begin{array}{l}\text { Level 2: } 89 \% \\
\text { Level 3: } 55 \%\end{array}$ & \\
\hline
\end{tabular}

\section{Extent and analysis of mismatch}

The study results suggested a marked discrepancy between the literacy demands of the programmes and the literacy levels of offenders required to attend them. The reading and writing skills of $57 \%$ of offenders were below Level 1 , but the delivery of all the programmes demanded reading skills at the 11-year-old level or above. O ffenders' skills in speaking and listening also appeared to be mismatched with the demands of the delivery of all three programmes. Evaluation of the speaking and listening demands for the programmes showed that offenders needed skills at least at GCSE A*- C level and frequently at higher levels in spoken communication skills for all sessions. However, only $26 \%$ of offenders appeared to have skills at this level.

In practice, tutors have some discretion over how to deliver programmes. Additional qualitative data were collected to determine whether tutors appeared to mediate the demands of the programmes (for example by adapting the language used to suit the literacy skills of the group). This involved observing programme sessions (12 observations - 4 per programme, plus video recordings of 9 sessions), and qualitative data from interviews with offenders and questionnaires completed by tutors (15 responses from tutors, 14 offender interviews, covering all 3 programmes).

\section{Mediating literacy demands}

0 bservations and offender interviews suggested that tutors were not always successful in varying programme content for groups of offenders with different literacy skills. However, tutors did not always have information about the literacy skills of offenders on their courses.

Tutors and offenders commented on the demands in the early sessions:

People are put off by the psychometric tests and the complexity of the first few sessions. (Tutor on $R \& R$ )

Sessions 1 to 4 were difficult to get the hang of ... I didn't understand what they were going on about. (O ffender on Think First)

Another theme was the pace of the programme as an additional difficulty faced by adults with poor literacy skills is that of working at speed. Tutors commented on the difficulties posed by the speed of the sessions and meeting the needs of offenders in the groups.

$O$ bservations and interviews suggested that offenders had problems with the vocabulary and language structures of the programmes. There were also presentational problems with the messages conveyed by the words and the context. This meant that some offenders were unable to understand and participate in the teaching:

The tutor doesn'talways explain it - they have to use the words from the programme and it doesn't always make sense. W e would understand it better if the language was easier. ( $O$ ffender on $R \& R$ )

There were examples of some tutors changing programme language and vocabulary to make it more accessible, but this was not always successful in improving offenders' understanding. It is difficult for tutors who have little 
experience of literacy problems to appreciate the level and extent of offenders' difficulties with language.

At the same time, tutors needed to ensure that offenders whose skills were more advanced were not alienated. However, many positive comments were made about the three programmes by tutors and offenders. Some tutors felt that offenders with poorer literacy skills often benefited from the role and support of more able peers. Some offenders said that they found it easier to learn in a group. Tutors commented that demands for writing (for example, in assignments and writing on flipcharts) caused difficulties for offenders. These difficulties may reflect the fact that the initial assessment did not test offenders' abilities to write text in sentences and the assessment results may lead to an over-estimation of their abilities to complete activities like assignments and handouts. Tutors reported that assignments were poorly completed, if at all, and they had problems introducing activities that required writing.

0 verall, it was clear that some tutors were making great efforts to deliver the programme in an accessible way. However, these efforts were not always as successful as they might have been. This led to uneven delivery of the programmes in terms of literacy, with tutors attempting different strategies with differing levels of skills and so achieving varied success.

\section{Conclusions and recommendations}

There was a mismatch between the literacy demands of the programmes and the skills levels of offenders. This was particularly significant in speaking and listening skills. Recommendations include:

Tutors - they were the key to the successful delivery of the programmes and some were more able than others to accommodate the literacy needs of offenders. Tutors and caseworkers need training in literacy, including interpreting and understanding assessment information and how to modify their teaching to accommodate the needs of offenders with poor literacy.

Programme materials and manuals - these should be adapted to accommodate literacy needs. Changes should address vocabulary, language, cultural influences, suggested methodologies for conducting activities and support materials for tutors delivering the programmes.

Literacy support - there were examples of support working well in some probation areas, including the use of a literacy support worker within sessions, dedicated and linked literacy support outside sessions and peer support In addition, literacy teaching prior to programme commencement could be considered although offenders with skills below Level 1 would require significant investment in terms of teaching to raise their levels quickly. This might cause significant delays in terms of referral to a programme. Supporting offenders after commencement on a programme using a variety of approaches may be a more realistic alternative.

A ssessment of offenders' skills - literacy assessment information covering reading, writing, speaking and listening should be available to programme tutors for all offenders.

Further research - a research study covering a longer period could measure the effects of low literacy levels amongst offenders attending general offending behaviour programmes, in terms of attrition rates and postprogramme outcomes.

The Home 0 ffice is preparing an action plan in response to the research.

\section{Methodological note}

The initial assessment was a 20 -minute multiple choice test that can discriminate an offender's literacy level at each of the levels from pre-entry to Level 1 by assessing reading at word, sentence and text level, spelling and some grammar and punctuation. This test was designed and piloted in 2002 by the Basic Skills Agency on behalf of the DfES and is used nationally in the correctional services. However, the test does not give an assessment above Level 1 , nor does it assess speaking and listening, so a test from the Diagnostic Assessment tools was adapted and a new checklist was developed for this study. A $n$ initial review of the programme manuals suggested there might be demands for reading above Level 1 in the programmes. An easy to deliver and brief assessment of reading comprehension at Level 2 was adapted to be administered to all offenders who reached Level 1 on the initial assessment. A lso, as no initial assessment of speaking and listening was available, a contextualised checklist was designed for this project. Probation staff received training in the use and scoring of the checklist and the results were monitored throughout the project.

\section{References}

DfEE (1999). A fresh start. Sudbury: DfES.

DfEE (2001). Skills for life. N ottingham: DfES.

DfES (2003). Skills for life, focus on delivery to 2007. Notting ham: DfES.

Hollin, C., M cG uire, J., Palmer, E., Bilby, C., Hatcher, R. and Holmes, A. (2002). Introducing Pathfinder programmes into the Probation Service: an interim report. Home 0 ffice Research Study N 0. 247. London: Home O ffice.
Q ualifications and Curriculum Authority (1999) Key Skills Units Levels 1-3, Sudbury: Q CA.

Vennard, J., Sugg, D. and Hedderman, C. (1997). Changing Offenders' Attitudes and Behaviour: What W orks? Home 0 ffice Research Study N 0. 171. London: Home $O$ ffice. 